\title{
Islamic Values in Muslim Housing Griya Sakinah Residence and Influence on the Behaviour of Its Residents
}

\author{
Mohammad Sahid Indraswara; Gagoek Hardiman; R Siti Rukayah; Fahmi Syarif Hidayat \\ Department of Architecture, Faculty of Engineering, Universitas Diponegoro, Indonesia
}

Corresponding e-mail: sahidarc@gmail.com

\author{
Article info: \\ Received: 26-9-2021, Revised: 27-10-2021, Accepted: 27-11-2021
}

\begin{abstract}
The development of housing that carries Islamic values has grown rapidly in the last 10 years in line with the increasing economic potential and awareness of Muslims to get a conducive environment for families, making developers build housing with Islamic concepts. This study aims to determine Islamic values that are embodied in the area, housing units and determine their influence on the behavior of its inhabitants. The research method used is descriptive analytical, namely revealing facts on objects in the present time. The results showed that the Griya Sakinah Muslim housing applied Islamic values to the area, facilities and housing units, namely the Hablumminallah in the form of a mosque which functions as a worship space and socialization space for residents of housing and local residents. The value of Hablumminannas is manifested in the construction of public facilities in the area and Hablumminalalamien is manifested in the construction of gardens in housing and the form of residential units with tropical architectural concepts in accordance with the local climate and environment. What has not been noticed is the value of death reminders in the form of tombs for residential residents. The new thing found in this study is the role of mosques to overcome social segregation in housing areas with cluster concept and further research needed about hijab in Islamic settlement.
\end{abstract}

Keywords: Islamic Values, Islamic Settlement, Muslim Housing

\section{Introduction}

Housing in UU no 1 tahun 2011 means a collection of houses with facilities and infrastructure that meet the needs of their residents. The large potential of Muslims, as well as the tendency of the community to get a conducive environment for families, and facilities that are in accordance with Islamic values are factors that make people interested in housing with Islamic concepts. (Aini, 2015; Nurrahman, 2010). Islamic housing is housing that is planned and built based on references from the Quran and Hadith (Aini, 2015; Edrees, 2010; Indrawati, 2019; Nurjayanti, 2019a; Priyoto, 2012). In its planning, Islamic architecture distinguishes in three scales, namely the macro (city), mezzo (area) and micro (residential) scale (Indrawati, 2019; Nurjayanti, 2019b). Muslim cities generally distinguish buildings into public and private buildings. The word muslim means people who are Muslim. So that a Muslim city means a city inhabited by people who are Muslim, as well as Muslim housing is housing inhabited by people who are Muslim (Nurjayanti, 2019a).

The development of housing with Islamic concepts has grown rapidly in the last 10 years (Asosiasi Developer Property Syariah, 2021). This growing phenomenon is an opportunity for developers to develop housing with Islamic concepts (Arifin, 2017). Each developer has its own references and thoughts about the concept of Islamic architecture. Aspects in Islamic housing based on Islamic values are based on three principles, namely, property design, property development, and financial transactions. Not all developers apply these three aspects in their formulation (Helen \& Gamal, 2017). 
In the Islamic Architecture webinar paper, it is mentioned the characteristics of Islamic architecture in contemporary Islamic housing, one of which is found in Griya Sakinah Residence Housing. Griya Sakinah Residence Muslim housing is located in Gedongan, Colomadu Surakarta, built by AUM (Muhammadiyah Charity). Griya Sakinah Residence Muslim housing is divided into four clusters in one area, namely Sakinah 1, Sakinah 2, Sakinah 3 and Sakinah 4. In The Production of Space (Lefebvre, 2000), it is stated that space is formed to "direct behaviour and thoughts" with symbols, name and justification, in this study the justification for housing is "Muslim housing". Space is represented according to Islamic values by architects on regional patterns and facilities in residential areas. Here the representation of space is tested by looking at the community's response to the concept made by the architect, especially the application of Islamic values in Griya Sakinah Housing. The concept of Islamic architecture which is applied to the Griya Sakinah Residence housing is interesting for further research with the following research questions:

1. How are Islamic values manifested in the Muslim Housing Griya Sakinah Residence Gedongan, Colomadu Surakarta?

2. How does the application of the concept of Islamic Architecture affect the behaviour of its inhabitants?

\subsection{The aims of this research are as follows:}

1. Establish Islamic values that are embodied in the Bumi Sakinah Residence Muslim Housing Gedongan, Colomadu Surakarta.

2. Determine the influence of the Islamic Architecture concept on the behavior of its residents in everyday life at the Muslim Housing Griya Sakinah Residence Gedongan, Colomadu Surakarta.

\subsection{The benefits of this research are as follows:}

1. For science, this research contributes to the knowledge of the realization of Islamic values in housing with Islamic concepts.

2. For the general public, this research can provide knowledge to develop and choose housing with Islamic architectural concepts that apply Islamic values correctly.

\section{Methods}

The research method used is descriptive analytical method, which is a method that reveals facts on objects at the present time. In data collection, there is no treatment or manipulation of the object under study in order to describe the variables, symptoms or conditions objectively. Data collection was carried out by direct field surveys and looking for secondary sources from the internet and structured interviews (interview guide). The data obtained were compiled and analysed by looking for the suitability of the parameters of Islamic values in Islamic housing and classified based on existing values to draw conclusions. (Prastowo, 2011).

The research locus is the Muslim Housing Griya Sakinah Residence located in Gedongan, Colomadu, Karanganyar, Central Java 57173. The location can be seen in Figure 2.1. 


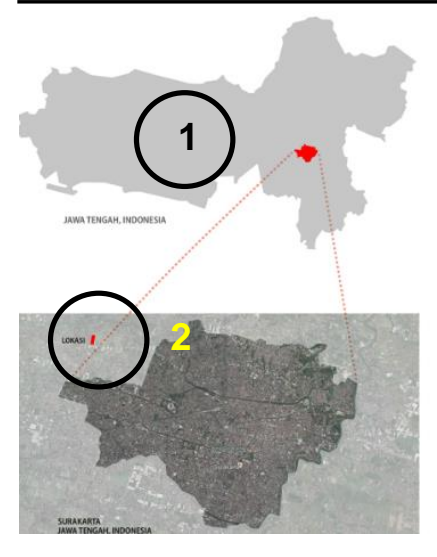

Caption:
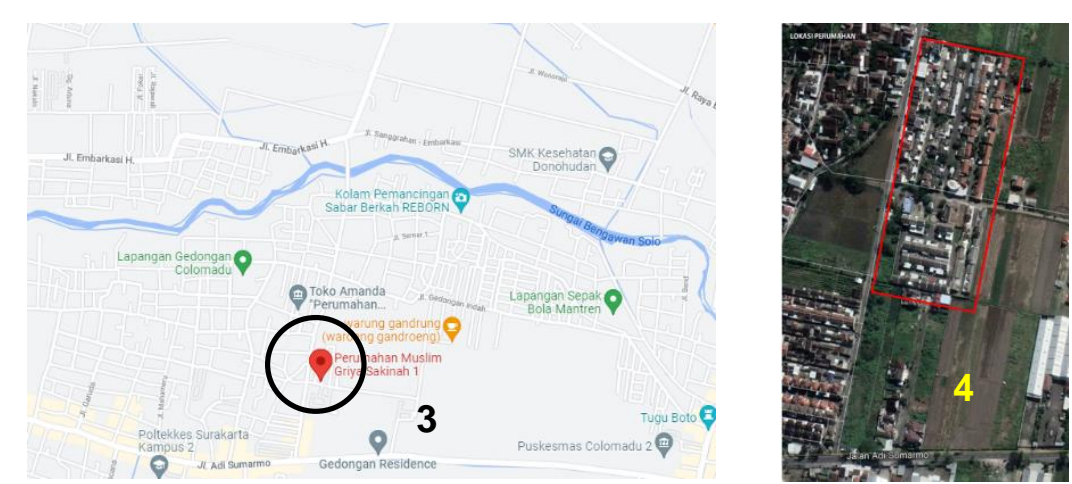

Figure 2.1. Research Locus

Source: google earth, 2021

1. The position of the city of Surakarta in relation to Central Java

2. Position of locus towards the city of Surakarta

3. Map around the locus

4. Site plan locus

\section{Result and Discussion}

Muslim Housing Griya Sakinah Residence is located in Gedongan, Colomadu, Karanganyar, Central Java 57173. The housing was built by AUM Properti (Amal Usaha Muhammadiyah) from 2010 to 2018. The housing is separated by a neighbourhood road and consists of 4 housing clusters. Muslim housing Griya Sakinah Residence 1 was built around 2010 by the Muhammadiyah University Cooperative for employees and lecturers of UMS (University of Muhammadiyah Surakarta) with a cluster concept. The type provided at the beginning of the construction was type 36 . Along with the increasing response from the community, the Muslim housing cluster Griya Sakinah 2, 3 and 4 was built by AUM Properti (Amal Usaha Muhammadiyah) which is a development of the Cooperative. Sakinah 1 cluster was handed over to residents from 2011-2012, and formed the Sakinah 1 Housing Association with the chairman of the association Mr. Yanuar having his address at Griya Sakinah 1 no 6 . Sakinah 2 housing was handed over in 2012, Sakinah housing 3 was handed over in 2014, and Sakinah housing was handed over 4 handovers in 2018. Sakinah Housing 2, 3 and 4 formed the Housing 2-4 community, with the chairman of the association Mr. Heri Susanto with the address Griya Sakinah 2 no B4.

In Islam, daily life is considered as worship, special worship (Zakat prayers, fasting, etc.) is called mahdhoh and those related to others and other activities are called ghairu mahdhoh. To facilitate worship activities, it is necessary to implement housing facilities that are in accordance with Islamic values so that our behavior and thoughts are always maintained for worship and ensure a relationship with Allah (hablumminallah), with humans (hablumminannas), and with the natural environment (hablumminalalamin) (Edrees, 2010). In Griya Sakinah Muslim housing, Islamic values are manifested in public facilities in the form of mosques which are the vocal points in residential areas, open spaces, parks, basketball/volleyball courts, wide roads, well-maintained regional utilities. The morphology of the area formed is in accordance with the settlements that become Islamic housing, namely 1. 
The mosque is the center of activity and focal point in the area (Aini, 2015; Amri et al., 2015; Nurrahman, 2010; Priyoto, 2012) 2. Open space as a place to socialize. 3 . The market in this context is planning for shophouses. (Priyoto, 2012). For more details about the location of the facilities in the Griya Sakinah Muslim housing, see Figure 3.1.

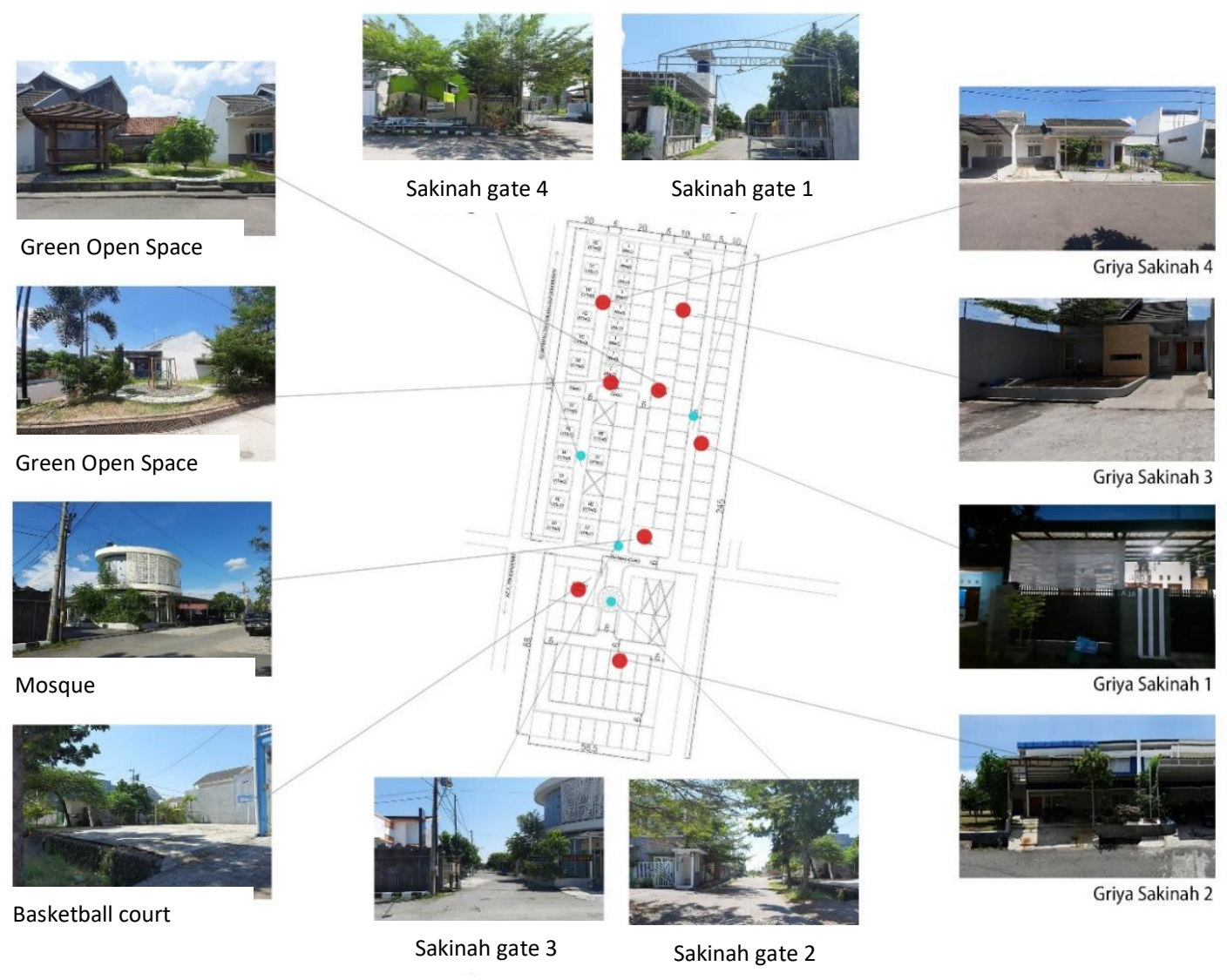

Figure 3.1. Site plan and housing facilities Source: author survey, September 2021

3.1. The relationship with Allah (habluminallah), has the following basic principles:

1. Reminders of worship and struggle, in the context of mahdhoh and ghoiru mahdhoh/muamalah worship. The mosque, not only as a place of worship rituals, but for ukhuwah and community activities such as sports, education, discussions, etc. (Utaberta, 2011).

a) In the Bumi Sakinah Residence Residential Area, the mosque is placed at the very front of the residential area. The mosque is the focal point of the area and makes it easier for residents to worship. In addition, the position of the mosque on the side of the main road is a place for interaction between native residents and residents of housing, as well as a resting place for people in need (sales, farmers, traders and people who happen to pass near the mosque). The atmosphere in the mosque was taken before the Dhuhur prayer on September 18, 2021. Many residents from outside the housing and local residents took a rest to mingle with the residents. For details, see Figure 3.2. below. 

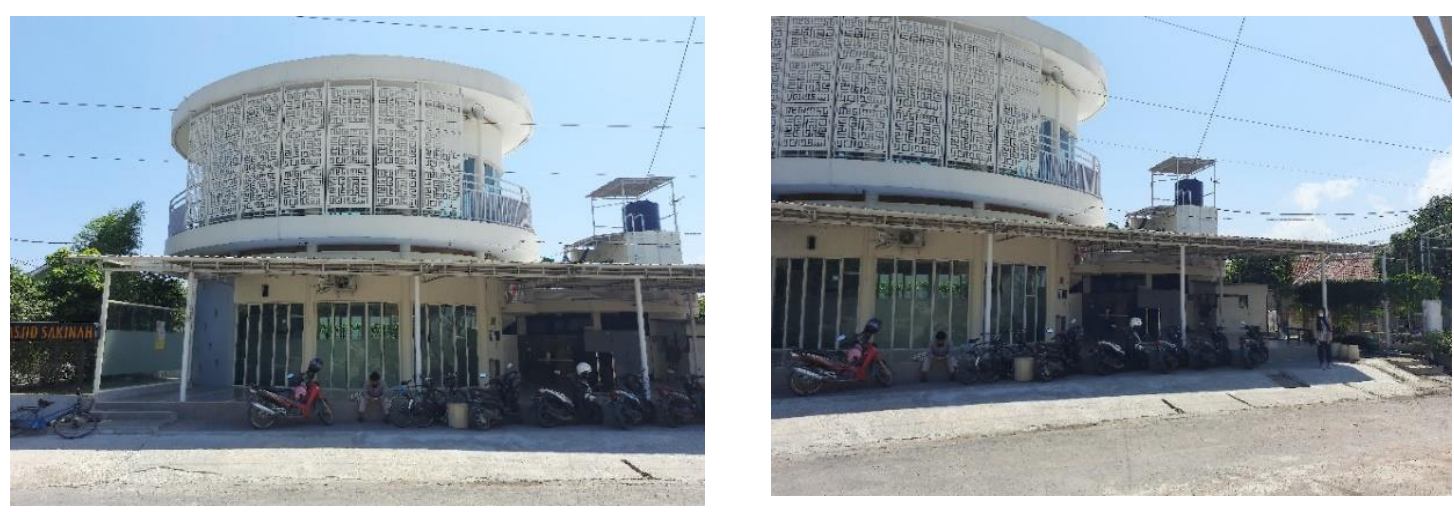

Figure 3.2.

Mosque Facility as vocal point

Source: Author Survey, 2021

b) The mosque becomes a center of activity for residents of housing in social activities and a place of acculturation/mingling with local residents. The role of the mosque as a place of worship for mahdhoh, a place to socialize for housing residents, as well as a place of acculturation with local residents is a counterweight and neutralizer of the concept of exclusive housing (cluster system). Many activities are carried out inside and on the terrace of the Oval Mosque, as shown in Figure 3.3.
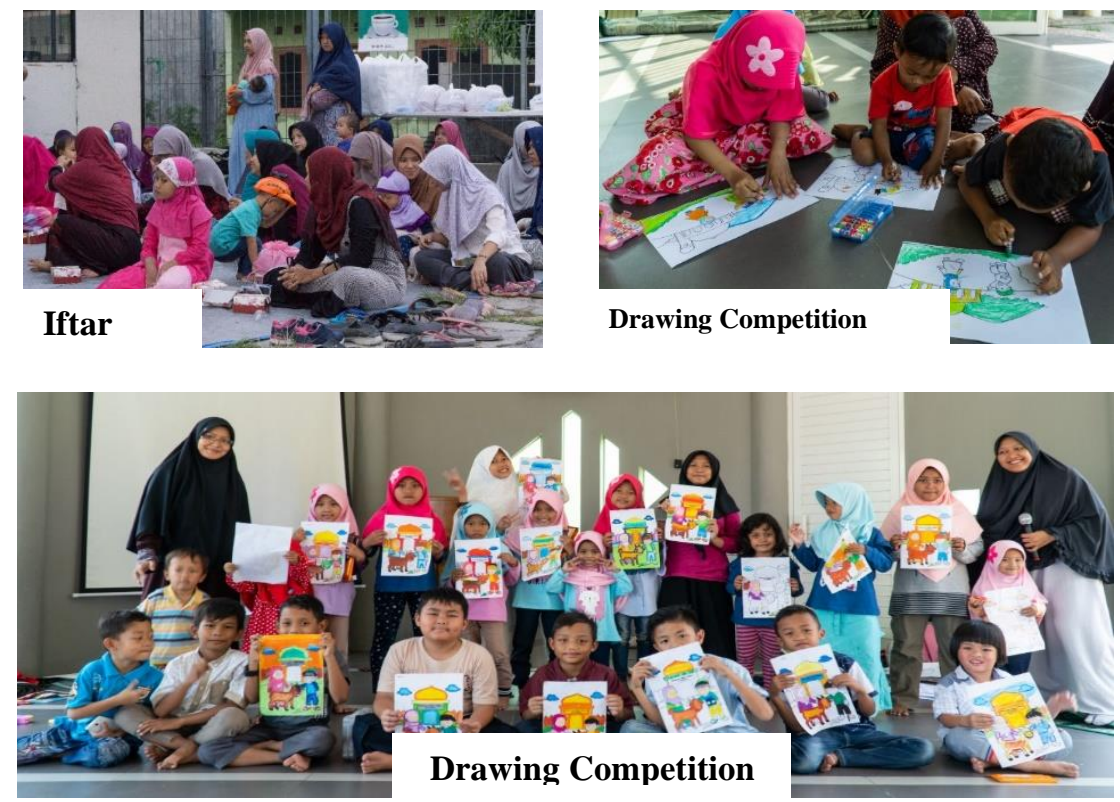

Figure 3.3.

Mosque as Activity Centre Source: Community Documentation

2. The principle of a reminder of death, manifested in the form of a tomb that is easily accessible and seen or marked as a tomb (Utaberta, 2011).

For the death reminder value in the form of a funeral, it has not been provided by the developer, so that if there are residents who die, they are buried in public cemeteries. Interviews conducted by the researcher on September 17 with the head of the Sakinah community, Mr. Heri who lives in Sakinah 2 no B4 and Mrs. Suryaning Setyowati, a resident who lives in Sakinah 3 at separate times. From the interview, it was found that several things were similar and related to the mosque at Perumahan Griya Sakinah. 
The mosque is often used by residents for all community activities, not only for worship, such as drawing competitions, TPQ, a meeting place for housing residents from clusters 1,2,3 and 4 as well as with native residents and immigrants who worship at the Oval Mosque. For funeral problems, if there are residents who die, they are usually buried in nearby cemeteries or taken to the city's public cemetery or brought back to their place of origin.

3.2. Relationships with fellow humans (Hablumminannas), there are basic principles in the form of:

1. Waqf and public welfare, which are implemented in public and social spaces (Utaberta, 2011). Griya Sakinah Residence housing has several facilities that are used very well by its residents. The park in Sakinah 3 and 4 cluster housing is a comfortable area to interact with fellow residents of the housing, the volleyball court in the Sakinah 2 cluster is a sports facility and a place for activities and community gatherings. The picture shows the function of the field and open space for various activities, as shown in Figure 3.4. below:
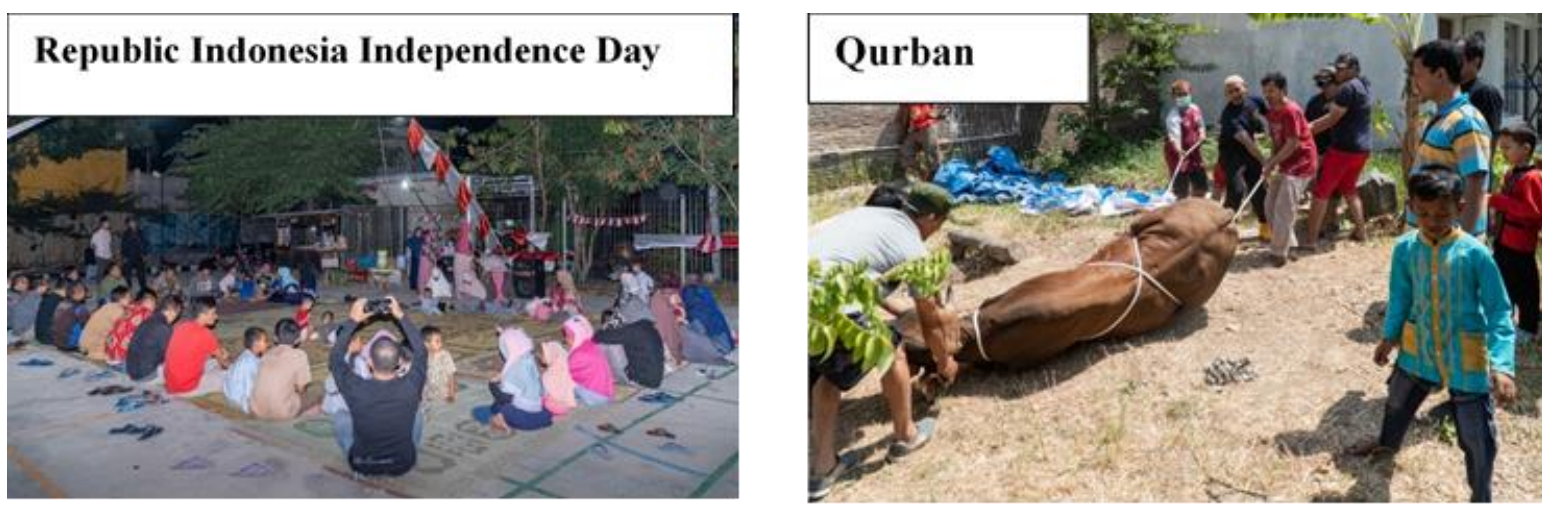

Figure 3.4.Activities in public spaces (public facilities) Source: Community Documentation

2. Cultural tolerance, which is applied with tolerance and cooperation with all human beings from all diverse backgrounds (Utaberta, 2011). There is assimilation in community social activities in residential areas. Residents of housing lots use ART (Household Assistants) who are local residents. Buying and selling activities with local residents who sell daily necessities into each cluster are going well according to the rules that have been agreed between residents and traders. In addition, in the housing there are native residents who are security and cleaning officers in the housing environment, as shown in Figure 3.5.

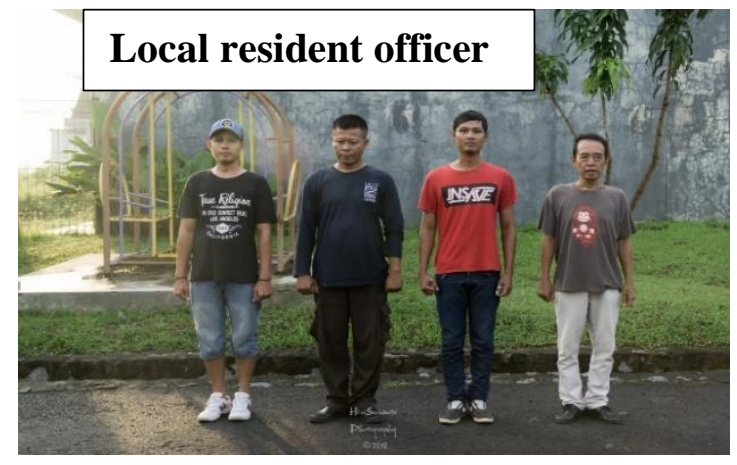

Figure 3.5.

Recruitment of Local Residents

Source: Community Documentation 
3. The principle of openness to the public. Including the obligation to avoid things that can interfere and threaten public safety (Utaberta, 2011). An association was formed to regulate public order on the basis of the principle of openness. The management of the area is handled by the community formed by the residents. Financial management is made openly and transparently. There are two associations in Griya Sakinah Housing, namely the Sakinah 1 community which consists of 30 families, most of whom are UMS employees. Physically has a gateway into the cluster, and a dead end within the cluster. The type of house in the cluster is type 36 with a fenced yard. Some of the houses appear to have been renovated and many are original. The residential road in the Sakinah 1 cluster is the narrowest street and is the cheapest type compared to other clusters. Community activities have been going well in the form of our monthly meetings of gentlemen, women's monthly meetings, series of commemoration of Indonesian independence, breaking fast with Ramadan, joint business units in the form of gallon drinking water and LPG gas, catfish aquaculture, healthy walks every two months, blood donation every two months in collaboration with PMI Surakarta, joint sports every Sunday morning and evening, and a mobile library. Activities are carried out at residents' homes, as well as on the road in front of the house that has been appointed.

Paguyuban Sakinah 2-4 consists of 3 clusters with a total of 56 families, most of whom are lecturers, employees and general buyers. Griya Sakinah 3 and 4 consist of separate clusters connected by a small road and a garden as a public facility. In general, the house is still original and some have been renovated. The initial concept of the cluster was without a fence, although there were some who used a fence in the Sakinah 3 and 4 clusters. The types of houses in the two clusters averaged type 45 with varying land areas. Griya Sakinah 2 is located opposite to Griya Sakinah 1, 3 and 4. It consists of a large type house on the front and type 45 on the back. In this Sakinah 2 cluster, all the houses are not fenced and are still original. Social activities for community members 2-4 consist of weekly Pengajian Ahad Pagi, Monthly Community Meeting Activities, Annual Activities including RI Anniversary Celebrations, Religious Holiday Celebrations (Eid al-Fitr and Eid al-Adha). The place of activity is on the volleyball court at Griya Sakinah 2 by involving all members of the community. For religious activities carried out at the residential Oval Mosque which is located on the side of the main road. This activity was carried out by all residents of Sakinah 1-4 housing and other residents. As shown in Figure 3.6. below:
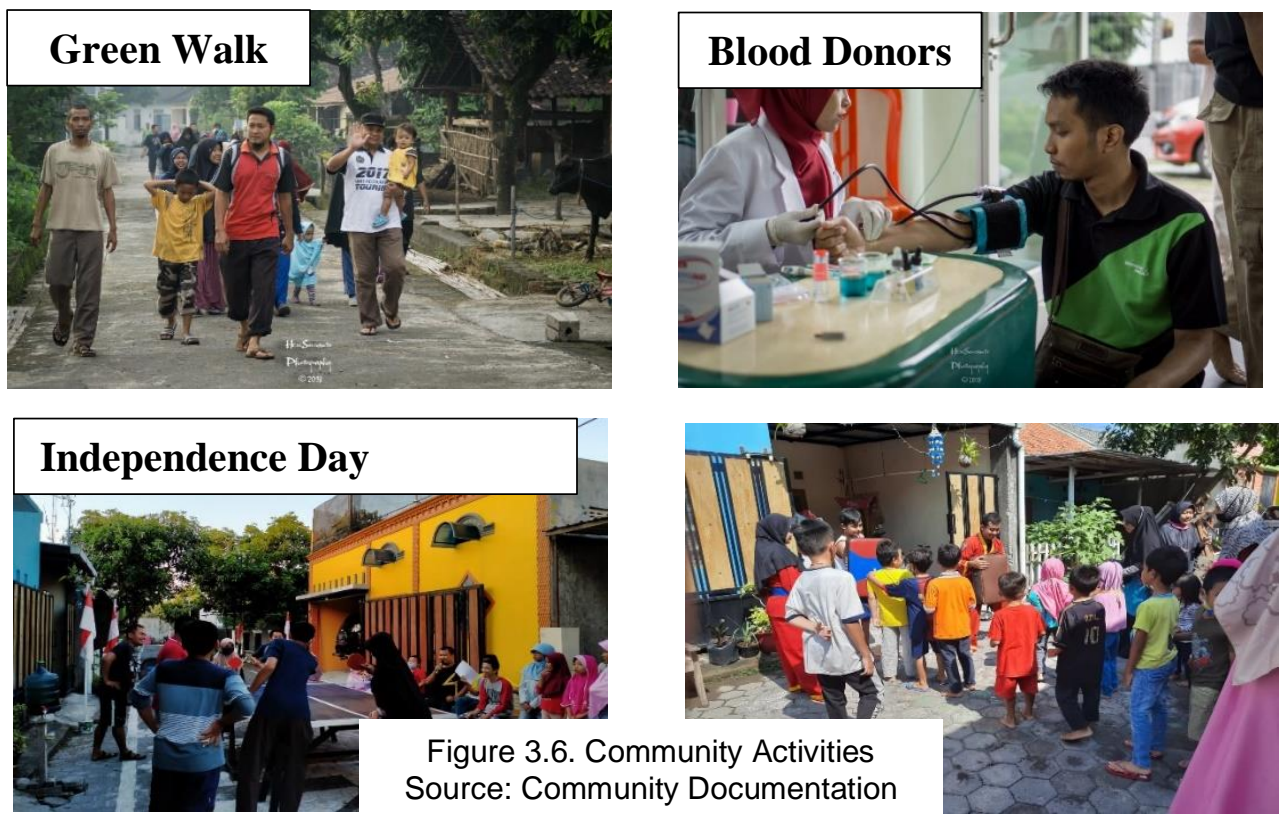
4. The concept of Hijab, is a barrier or cover. Hijab can be in the form of a physical hijab (permanent, semi-permanent) or a behavioural hijab (Indrawati, 2019).

The hijab concept affects privacy and control based on understanding the hijab concept and the division of space levels in use. as a form of supervision with the aim of 1) creating comfort and the environment. (Roihanah et al., n.d.). 2) Establish visual and sound privacy in the built environment (Triyosoputri, 2011). 3) Muslim visual security affects four things, namely genital protection, security, community interaction, and (Manaf et al., 2019). In housing planning, privacy can be formed from road patterns. The cul-de-sac road pattern is a road pattern that creates the highest privacy and the lowest traffic level (Chiara \& Koppelmen, 1990; kemenpera, 2011; Kwanda, 2000). Development with the above patterns in addition to having high privacy also creates exclusivity in the community in housing (Elanda, 2019; Sunesti et al., 2021).

In Griya Sakinah Muslim housing, the area pattern is a cluster and the road pattern is a culdesac (dead end), only residents and interested people enter the cluster, with supervision from residents. For more details can be seen in Figure 3.7.

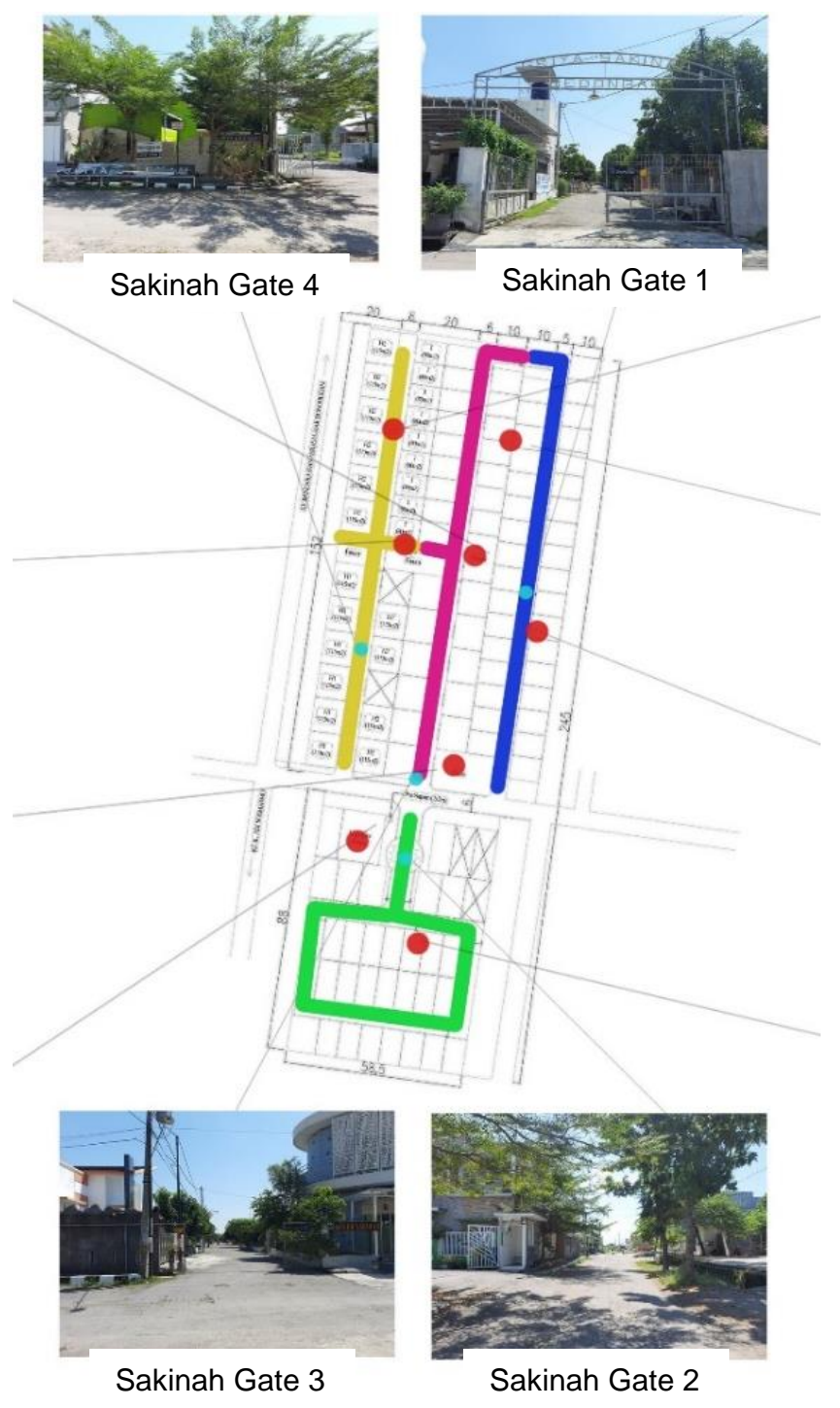

Figure 3.7. Gates of Housing

Source: Author survey, September 2021 
Visual privacy is seen in the arrangement of the housing units towards the neighbourhood road, so that the occupants' activities are not visible from the road. Along the main road, you can see a massive wall of people's houses, as shown in Figure 3.8.

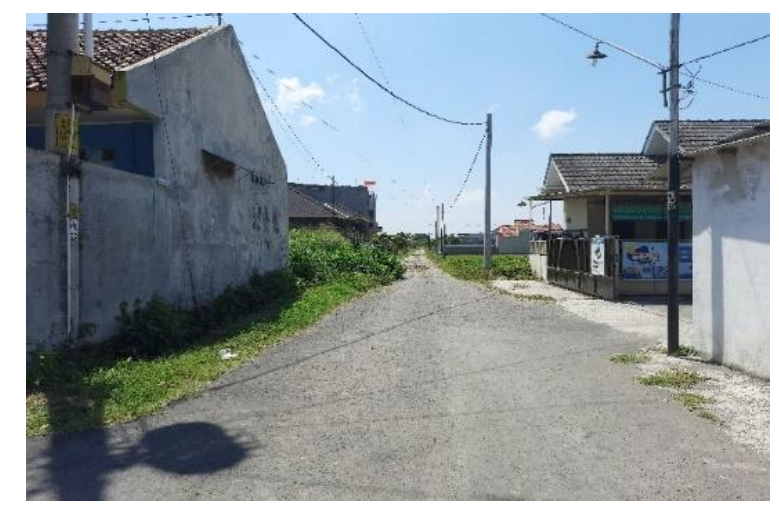

Figure 3.8.

View of housing from the main road

Source: Author survey, September 2021

With this pattern the security and comfort of the residents of housing is more guaranteed. Low noise level is another thing that can be achieved by applying this concept. The cluster system also allows bonds in housing to be very strong, so that the environment is more protected from things that are less safe (crime) and less comfortable, such as unpleasant odours from the sewers.

Interviews conducted by the researcher on September 17 with the head of the Sakinah Community, Mr. Heri who resides in Sakinah 2 no B4 and Mrs. Suryaning Setyowati, residents who live in Sakinah 3 at separate times, mentioned by Mrs. Suryaning that initially it was Sakinah 1, 3, and 4 are connected by a small 3-meter-wide road. The road was closed in 2016 due to frequent thefts and thieves fleeing through the connecting road at Sakinah 1. This happened because Sakinah 1 entrance and exit was relatively far from the guard post. Finally, residents of Sakinah 1 used the mosque as a place to gather and socialize with other cluster residents. Utilization of the facilities in each cluster (except Sakinah 1) is very optimal, especially the park in the area as a place for children to play and relax. Likewise, these facilities can be used for community gatherings. Even if residents object to their residence being the host for activities, they can borrow public and social facilities as a place. In general, residents choose the mosque as a closed place and a field during outdoor events. Mrs. Suryaning's statement was agreed by the head of the Sakinah Society 2 to 4.

c. In maintaining harmony with the environment (Hablumminalalamien), there are values (1) The principle of remembering God, by showing the greatness of nature as God's creation and integrating nature with buildings. (2) The principle of humility, which is implied by placing and arranging the building mass contextually with the environment (Utaberta, 2011). The housing design of Griya Sakinah Resident applies a tropical building typology with a sloping roof and wide trestle, in harmony with the humid tropical climate and local environment. Buildings that are made to unite with nature with garden in the area. 

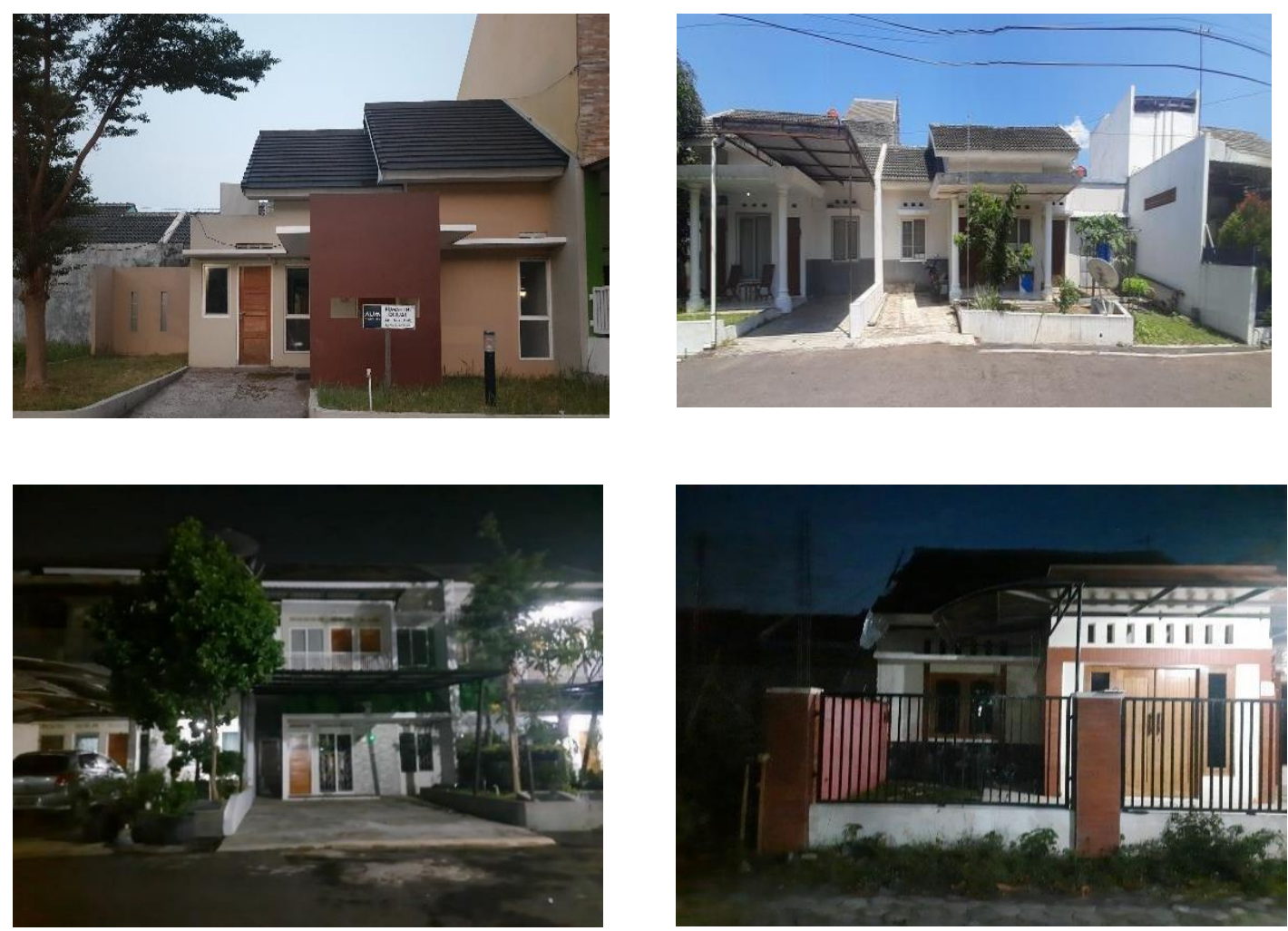

Figure 3.9.

Façade of Residential Unit

Source: Author survey, September 2021

For the design of the building, said Mrs. Suryaning in her interview, in the middle of the housing development stage, the design of the house is freely determined by the consumer, so that in housing there are sometimes several different models. This is based on consumer demand not to renovate again in the future.

From the results of the discussion above, there are several interesting findings to discuss, namely the mosque in the housing area functions as a community space for all levels of society and is placed as a vocal point, this indicates the importance of the function of the mosque in the housing (Priyoto, 2012). Interestingly, the Griya Sakinah Muslim housing estate which was built with the Cluster concept for reasons of privacy and security makes housing exclusive and often creates social segregation (Vinkovic \& Alan, 2006). With this, the mosque plays a role as a centre of activity as Rosulallah has done and exemplified in building the city of Medina when he first migrated (Priyoto, 2012; Saputra \& Rahmawati, 2020).

Hijab is one of the values of Islam with purpose to maintain connection with God (Habluminallah), and maintain connection with other people (Habluminannas). The implementation of hijab, can be seen in ourself, residence, and housing area.

\section{Conclusion}

Islamic values are manifested in facilities within Griya Sakinah Residence Muslim Housing, namely maintaining a relationship with Allah (hablumminallah), fellow human beings (hablumminannas) mainly applied with open space area within the housing and harmony with nature (hablumminalalameen). The basic principle which is the translation of Islamic values is 
almost all applied in residential area facilities except for the value of death reminders (cemeteries).

The Islamic values applied to the Griya Sakinah Muslim Housing are widely implemented in the activities of housing residents and local residents. Optimal use of facilities in community activities encourages residents to behave in accordance with Islamic values. Prayer activities are well accommodated in affordable mosques. Other religious activities can also be carried out in the mosque or in the field. The number of parks and open spaces in each cluster encourages very good socialization between fellow residents. Relationships with local residents can also be established through mutually beneficial activities.

\section{Recommendation}

Further research is needed on the role of mosques to overcome social segregation, especially in housing with the cluster concept. And further research needed about hijab in Islamic settlement.

\section{References}

Aini, N. (2015). Respon Masyarakat terhadap Konsep Perumahan Berbasis Agama: Perumahan Islami. Prosiding Temu IImiah IPLBI 2015 / C 077, 77-84.

Amri, N., Imriyanti, \& Ishak, R. A. (2015). Pola Tatanan Ruang Rumah Tinggal Di Perkotaan, Sesuai Dengan Prinsip Islam. Publikasi UMS, n.a. https://publikasiilmiah.ums.ac.id/bitstream/handle/11617/3546/8. Nurmaida Amri\%2C dkk - UNHAS.pdf?sequence $=1$ \&isAllowed $=y$

Arifin, kamil alfi. (2017). Perumahan Muslim dan politik Ruang di Yogyakarta. Jurnal Pemikiran Sosiologi, 4(2), 42-56.

Asosiasi Developer Property Syariah. (2021). Berdiri Teguh Di Tengah Badai. 16-17.

Chiara, J., \& Koppelmen, L. (1990). Site Planning Standart (J. Hakim (ed.); 2nd ed.).

Edrees, M. B. (2010). KONSEP ARSITEKTUR ISLAMI SEBAGAI SOLUSI DALAM PERANCANGAN ARSITEKTUR. Journal of Islamic Architecture, 1(1), 16-20. https://doi.org/10.18860/jia.v1i1.1712

Elanda, Y. (2019). Komodifikasi Agama Pada Perumahan Syariah Di Surabaya. In Jurnal AlHikmah (Vol. 17, Issue 1, pp. 41-62). https://doi.org/10.35719/alhikmah.v17i1.3

Helen, N. :, \& Gamal, A. (2017). Sharia Housing in the Real Estate Business. Iccrem, Mubarok 2015, 27-41. https://ascelibrary.org/doi/pdf/10.1061/9780784481059

Indrawati. (2019). Saujana pemukiman masyarakat islam. Diponegoro University.

Kemenpera. (2011). Permenpera no 25 tahun 2011 (Issue 646, pp. 1-26).

Kwanda, T. (2000). Penerapan Konsep Perencanaan Dan Pola Jalan Dalam Perencanaan Realestat 1 Di Surabaya. Dimensi : Journal of Architecture and Built Environment, 28(2), 1-1. https://doi.org/10.9744/dimensi.28.2.

Lefebvre, H. (2000). The Production of Space. Georgetown University Press.

Manaf, A. A., Rahim, Z. A., Majid, N. H. A., \& Omer, S. (2019). A relook at visual privacy: Definition and factors influencing muslim visual privacy (MVP). Pertanika Journal of Social Sciences and Humanities, 27(4), 2659-2670.

Nurjayanti, W. (2019a). Konsep Arsitektur Islam (1st ed.). muhammadiyah University Press.

Nurjayanti, W. (2019b). Micro and mezzo space pattern in Kampung Kauman Solo. AIP Conference Proceedings, 2114. https://doi.org/10.1063/1.5112444

Nurrahman, I. (2010). Respon Masyarakat Hunian Islami terhadap Ekonomi Islam. Al-lqtishad, II, 31-54.

Prastowo, A. (2011). Memahami metode-metode penelitian (M. Sandra (ed.); II). AR-RUZZ MEDIA.

Priyoto. (2012). Penerapan Konsep Kota Islami dan Pengaruhnya Terhadap Sosial Budaya 
Masyarakat Kasus: Perumahan REWWIN, Waru.

Roihanah, I., Pangarsa, G. W., \& Tjahjono, R. (n.d.). Konsep Privasi Visual Ruang Dan Keamanan Pada Permukiman Kampung Arab Malang * (pp. 101-106).

Saputra, A., \& Rahmawati, N. (2020). Arsitektur Masjid (I). muhammadiyah University Press.

Sunesti, Y., Putri, A. K., \& Anwar, M. Z. (2021). Sharia housing, sustainable communities and civic pluralism in Surakarta. IOP Conference Series: Earth and Environmental Science, 716(1). https://doi.org/10.1088/1755-1315/716/1/012087

Triyosoputri, E. (2011). Ekspresi Privasi pada Rumah Tinggal Keluarga Muslim di Malang. Seminar Nasioanal Life Stle and Architecctur, 320-330.

Utaberta, N. (2011). Rekonstruksi Pemikiran, Filosofi Dan Perancangan Arsitektur Islam Berbasiskan Al-Qur'an Dan Sunnah. Simposium Alam Bina Serantau Universiti Kebangsaan Malaysia.

Vinkovic, D., \& Alan, K. (2006). A physical analogue of the Schelling model. PNAS, 103(51). 